\title{
Balanced Literacy Model in Taman Baca Masyarakat Surabaya
}

\author{
Kartika Nuswantara \\ Faculty of Business and Management Technology, \\ Institut Teknologi Sepuluh Nopember Surabaya, \\ zettira@gmail.com
}

\author{
Zuliati Rohmah \\ Faculty of Arts and Humanities, \\ UIN Sunan Ampel Surabaya, Indonesia \\ kartikanuswantara.its@gmail.com
}

\begin{abstract}
In advancing children's literacy proficiency balanced literacy platform has a central role. A number of empiricalstudies exploring literacy programsamong school-age children have been administered in rural areas and/or low socio-economic groups of people. However, most of them are conducted under school setting. Explorations on the practices of literacy outside of the school setting are hardly found. In Indonesian setting, to the best of the researchers' knowledge, there has been only one investigationreporting on how literacy is encouraged in public library circles. To respond to this scarcity, the current study collected data from Taman Baca Masyarakat(Community Reading Gardens, henceforth, CRGs) in Surabaya, Indonesia. Responses from 292 female and 103 male teacher librarians collected from an online questionnaire were analyzed. The results of data analysis in Phase 1 describing the educational background and work experience of the CRG staff as well as their familiarity with the concept of Balanced Literacy become the basis of the implementation of the simplified Balanced Literacy Training in Phase 2.
\end{abstract}

Keywords: balanced literacy, Community Reading Gardens, teacher-librarians

\section{INTRODUCTION}

The launch of various international surveys on literacy indices, like The Trends in International Mathematics and Science Study (TIMSS) 2015 (Foy, 2017), Program for International Students Assessment (PISA)2015(Ibrahim, 2017), and the Progress in International Reading Literacy Study (PIRLS) 2016 (Foy et al., 2018)has made literacy studies become more stimulating to discuss. A number ofstudieshave been conducted to reveal how literacy practice is carried out in many different countries. For example, Walker (2015)has promoted a service-learning book drive project to help children in rural Ethiopian schools improve their literacy rate while schools in this developing country have less libraries and low access to any book resources. Similar study has also been administered in similar setting in China(Gao et al., 2018). The study attempts to revisit how reading instructions given to children in rural China can make reading skills as well as academic achievement improved. In Indonesia, literacy programs have received special attention in order to increase national literacy index. Therefore, literacy programs in schools are aimed to nurture literacy skills of the students all over the islands in the country, not to mention the remote area in Papua (Yektiningtyas-Modouw \& Karna, 2013).

There have been a lot of investigations exploring literacy practices among school-age children in rural areas and/or low socio-economic society, yet most of them center on the issue under school setting (see, for example, Frey et al., 2005; Chen et al., 2016; Rojas-Drummond et al., 2017; Law, 2011; and Andersen et al., 2018). However, few studies elucidate the practices of literacy outside school setting. Easton (2014: p. 26)introduced the idea of fostering literate environment as a response to the declaration of the United Nations Literacy Decade (UNLD) adopted by the General Assembly of the United Nations early in 2002.In his study, Easton shows how Africa attempts to eardicate illiteracy of the society by promoting literate environments which enable every individual to become literate and able to sustain, develop and integrate the novel knowledge to continue their better life. In such environment, literacy supply is given not only through the availability of reading and writing material, but also through an integration among opportunity to gain new literacy skills and durable demand for literacy training (p. 4). Other study for literacy practice under community setting is found in Uganda which has been carried out by Stranger-Johannessen (2014) to nurture community's reading culture by integrating it in a part of leisure activities.Another study is about the use of community libraries to support literate environment and sustain literacy skills in Nepal pioneered byShrestha and Krolak (2015). They propagate to use community library for empowering women to create new livelihoods from which their life welfares start toimprove. 
To the best of the researchers' knowledge, there has been only one research conducted in Indonesia that reports how literacy is promoted and fostered under the setting of public libraries (by Håklev, 2010). This research collected data regarding the profiles of the so called Taman Baca Masyarakat/TBM (Community Reading Garden/CRG)in the area of Greater Jakarta. This research investigates what happened at the Community Reading Park in the Jabodetabek area. Based on data collected from 87 Community Reading Parks (CRGs), Håklev(2010) explains various types of CRGs and government policies related to the reading garden. This study describes the activity of TBM in general. However, the weakness of this study is that there is no detailed activity report portraying the day-to-day activities in the CRGs.

Due to the lack of data available related to the issue of literacy practices in community or in public setting beyond school setting, the present study has chosen Taman Baca Masyarakat(TBM) Surabaya (henceforth: Community Reading Gardens (CRGs), as the setting for data collection. The purpose of this activity is that this community group has the opportunity to improve its literacy skills and then it will be followed by the ability to improve its improved standard of living.

The Literacy movement in the community has been initiated by the community, the community, as well as the central and local governments (Håklev, 2010), and one successful literacy program is a literacy program propagated by the Surabaya City Government. Surabaya has built 460 CRGs which are scattered in the city which includes districts, sub-districts and villages(Wijayanto, 2017). The purpose of the development of this TBM is to bring books closer to the community so that access to literacy development for all community members becomes wider. Another goal is to help community members develop their reading culture. Such programs are designed to support national policies to accelerate the increase in the number of literate people (see Håklev, 2010)

An interesting fact about CRGs in Surabaya is their strategy to attract visitors. In addition to being able to read, CRGs is a community learning center where they utilize the services of $\mathrm{CRG}$ officers to help complete school assignments of their children on primary and secondary school levels. This is recognized by the community as a program that is very helpful especially for children from disadvantaged families. With this program, the burden of children and parents to overcome learning problems in schools is solved.

In the operation of CRG activities in the city of Surabaya, the City Government through the Department of Library and Archives of Surabaya City has recruited staff who are specifically assigned to manage all library affairs for the community both in schools and in CRGs that are scattered throughout the city of Surabaya. They were recruited with basic tasks and functions to carry out various administrative and library assignments, including becoming admin staff and serving as managers managing the CRGs and libraries in elementary and junior high schools, but in reality they were demanded by the community to help solve children's learning problems or they were expected by the schools to help the administration outside the library. Hence,CRG officers have multi-tasks which include duties as administrative staff, librarians as well as teachers. This necessitates a person who has a variety of skills that enables him/her to carry out tasks and functions in CRG, especially because each officer will be responsible for managing one CRG and one school with part-time sharing (08.00-12.00) at school, and the rest (at $13.00-16.00$ ) is in the designated CRG. Thus, to achieve success in improving community literacy through the literate environment that was developed together with the establishment of CRG, a CRG officer who has multi competencies is needed in each CRG.

\section{METHOD}

A preliminary survey was conducted to photograph the real conditions in the field. The survey aims to recognize the competency background possessed by CRG officers. The survey was conducted to preview the competence of CRG officers in terms of their background and experience in managing CRGs based on the length of time they worked at the CRGs. Furthermore, the information obtained becomes the basis for the implementation of training activities. Thus this study is administered using two methods which are carried out in two stages. Stage I was administered by understanding the existing conditions by conducting a field survey by distributing questionnaires on an online basis to 460 CRG officers in the city of Surabaya.Stage II was the implementation of the Balanced Literacy training in the CRGs.

\section{FINDINGS AND DISCUSSION}

From the two stages that have been done, the following results are obtained:

\section{Phase I}

After the survey, an overview of the background of CRG Officers in the Surabaya City area was obtained. Through a questionnaire distributed online, there were $395 \mathrm{CRG}$ officers who responded to the questionnaire. The questionnaire was distributed using Google Form with the help of the Library Service and City Archive Service Coordinator so that the confidentiality of the officers' personal identity was guaranteed. From the collected data, information is obtained about educational background and length of work. 


\section{Educational background}

Regarding the education level of the CRG officers, Figure 2 shows that $25.8 \%$ of the officers have education up to the level of Middle School; but most of them, $66.3 \%$, have received undergraduate education. Officers

Figure 1. Education Level of the CRG

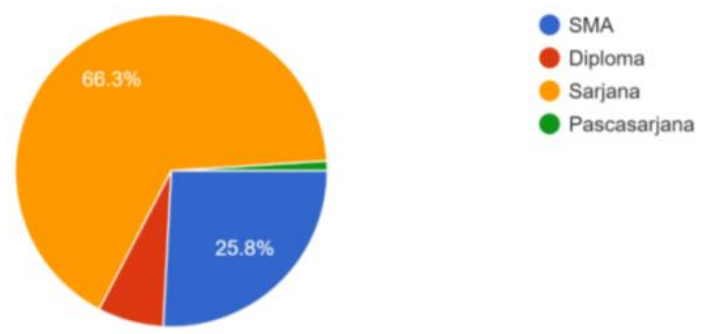

Focusing on the background of the study, it was found that $33.3 \%$ graduated from the Education Department which indirectlyinforms us that one third of theCRG officers had teaching skills, which is good to perform the teaching and coaching task. The second biggest amount of the CRG staff is from Accounting Department that does not have any relation to the tasks of CRG staff. The percentage of officers graduated from the Library Department is even in much lower category.

Figure 2. Educational Background of the CRG Officers
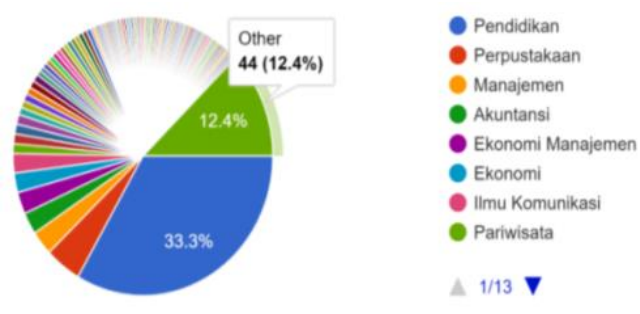

\section{Length of Work Experience}

In addition to educational background, the length of work is expected to be a source of information about the CRG officers. It is assumed that the longer their work experience, the better their ability to carry out multiple tasks as CRG officers. From the data, there are only $22 \%$ officers who have less than 1 year of work experience, $21 \%$ have work experience between 1-3 years, and the biggest percentage, which is, $56.2 \%$ have worked for more than 3 years. This is expected to be a positive aspect to support the success of the CRG officers to complete the tasks and achieve targets to increase the number of children to be more literate. This is because the success of a literacy program in CRGs is determined by the cognitive background and experience of the staff (Wijayanto, 2017) and (Wilkinson \& Birmingham, 2003).

Figure 3. Length of Work Experience of the CRG Officers

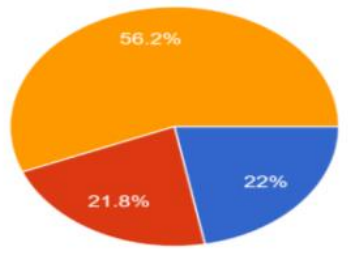

\section{Familiarity of CRG Officers with the Concept of Balanced Literacy}

Knowing the officers' familiarity with the concept of 'Balanced Literacy' is very essential prior to the implementation of the training. The team has surveyed the level of familiarity of CRG officerstobalanced literacy to help school-age children improve their literacy. Information obtained from the survey is very important to determine the types of balanced literacy activities that can be applied in the CRGs and determine the approach that can be applied by the officers in their respective CRGs.

Figure 4. CRG Officers' Familiarity with Balanced Literacy

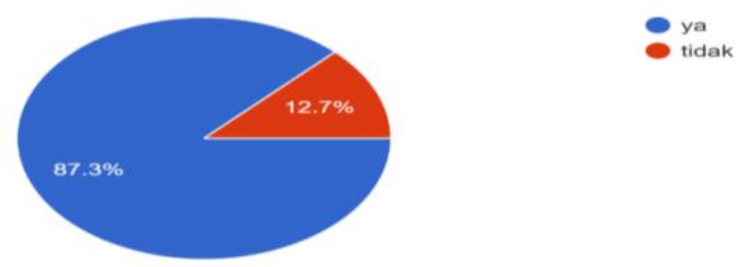

\section{Phase II}

Considering that the success of literacy programs depends on the cognitive background and experience of staff (Bingham \& Hall-Kenyon, 2013; Law, 2011), a training is carried out with the aim of helping increase the creativity of TBM officers, so that those who do not have pedagogy as the educational background or do not have enough work experience/period can increase their creativity in managing activities in CRGs. The Balanced Literacy Model implemented in the CRG staff training has been simplified so that in this model the Balanced Literacy only integratesfour components out of the eight components proposed by(Fountas, I., and Pinnell, 2001). The four components are reading aloud that is integrated in sharedreading, sharedwriting (interactive writing), guided writing, and independent writing.

The Balanced Literacy Model was introduced to the CRG officers through training and participation programs. The training involved 31 
children visiting the CRGs representing all subdistricts in Surabaya. 75 CRG officers were present as participant observers who were sitting in the room observing the course of the training so that they witnessed how the service team implemented a balanced literacy model with the children who were visiting to CRGs. This activity aims to provide mentoring through direct modeling so that the CRG officers are able to practice these activities in their respective CRGs later on.The training was conducted in three consecutive days (11-13 July 2019), and activities are described as follows:

\section{Reading Aloud and Shared Reading}

The reading aloud activity is known as the initial reading habit by reading a text with a loud voice. The advantage of this reading activity is to improve pronunciation, and encourage students and to increase self-confidence. The most important aspect in the practice of reading aloud is to use loud reading to interact with the others.

Reading Aloud activities in this activity are integrated in shared reading activities. In the Balanced Literacy model implemented in this activity, the children collaborate in groups to get information that can be obtained by reading a text. Given that only one text is provided, while each child must be able to solve a problem from the same text, so the childrenhave to do it by reading the book together. The text is taken from the authentic material, namely, newspapers. While the text is posted somewhere, the children must read together.Because they have limited time, it is not possible for them to read the text alternately. To make it easier to read the authentic text with specific size of fonts, one of them must read it in a loud voice so that the other friends can listen and get the information they need.

\section{Interactive Writing}

Another activity in the training is 'Interactive Writing' that was implemented by writing together in groups. After getting information from reading, they write information in their own language style on the board. After a kid writes on the board, the activity is then continued with the other group members until all group members write down the information they have obtained in the reading text. At the end, they improve the sentences they have composed to make them harmonious and develop coherence in the paragraph.

\section{Guided Writing}

Figure 5. Guided Writing
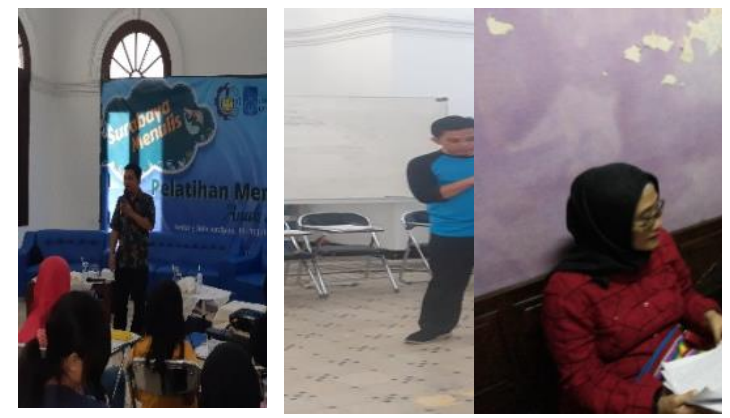

Guided writing is aimed to provide guidance and feedback as well as assistance so that the children can write well. At the beginning of the activity, the service team introduced a lot of pieces of information on the steps of creative writing. Then the children practice writing by referring to the information provided by the service team. In the writing process the service team provides feedback to improve content, plot, as well as language. After the training, the service team visits the training participantswho still have difficulties in writing at hometo motivate them and not get hopeless as a mentoring effort to support them.

\section{Independent Writing}

In this activity, the children are invited to write a story after they have received guidance and assistance on how to find ideas, develop ideas, and make a storyline. They write stories with the theme of their experiences or stories of imagination. They are also allowed to write about events that are happening around them. Freedom in choosing themes is expected to give freedom to the children to be creative.

\section{Discussion}

Based on a survey of the educational background of CRG officers, it is known that CRG officers with educational background are only $33.3 \%$. A low percentage compared to the main tasks and functions of CRG officers, one of which is to carry out teaching and learning tasks. Educational background in pedagogy will make it easier for CRG officers to carry out creativity in the field of learning. The officers tend not to be creative if they do not have a background in this field. This has been reported by Håklev (2010: 6)that the creativity of CRG officers was not satisfactory in terms of creating reading creativity in the CRGs and this was related to the educational background. However, based on the length of work, $56.2 \%$ of CRG officers have worked for more than 3 years. This is a little encouraging considering that theCRG officers have enough time to improve their ability in line with the training and coaching they receive throughout their tenure as CRG officers.

$$
\text { Balanced literacy proposed by }
$$

Fountas\&Pinnell (2001) has eight components, they are, reading aloud, guided reading, shared reading, 
reading independently, and followed by guided writing, interactive or guided writing, and independent writing. Several studies on balanced literacy have been successfully implemented in the school environment and are able to balance both skills namely reading and writing skills (see Frey, et al., 2005; Shaw and Hurst, 2012; and Bingham and Hall-Kenyon, 2013)). In its implementation in the CRGs in Surabaya, the componentsare simplified because the characteristics of visitors to the CRGs are not the same as students at schools. The conditions in the schools make it possible to apply all components because the students have higher motivation. Unlike the situation at schools, the situations in CRGs are different. Children come to the CRGs with diverse motivations. Some of them search for reading resources or just channel their hobbies to read, but not infrequently children make the CRGs a playground. By simplifying the components and packaging activities in a game, balanced literacy can still be applied even though it must be modified in such a way to adjust to the situation in the CRGs.The uniqueness of the CRG visitors should be recognized by the CRG officers so that they can adjust the components when applying the balanced-literacy in the CRGs. By

\section{CONCLUSION}

Applying the Balanced Literacy model, the CRG officers help improve the literacy skills of the kids through varieties of reading and writing activities. The two skills are the basis of the skills needed to solve learning problems. By practicing these literacy skills, the real life skills of children are also honed so that they become more confident and accustomed to dealing with the problems they have, especially related tohomework given by the teacher in the schools. Similar effort has been done by several researchers in public libraries in China, Uganda and Ethiopia (see Chen et al., 2016; Stranger-Johannessen, 2014; Easton, 2014). If the officers succeed in practicing the Balanced Literacy model in the CRGs, they will not be too busy in helping each child with different homework; the kids are expected to be able to complete their own tasks. With this situation, the officers can handle other administrative tasks.

\section{REFERENCES}

[1] Andersen, S. C., Christensen, M. V., Nielsen, H. S., Thomsen, M. K., Østerbye, T., \& Rowe, M. L. (2018). How reading and writing support each other across a school year in primary school children. Contemporary Educational Psychology, 55, 129-138. https://doi.org/10.1016/j.cedpsych.2018.09.005

[2] Bingham, G. E., \& Hall-Kenyon, K. M. (2013). Examining teachers' beliefs about and implementation of a balanced literacy framework. Journal of Research in Reading, 36(1), 14-28. https://doi.org/10.1111/j.14679817.2010.01483.x

[3] Chen, P., Rea, C., Shaw, R., \& Bottino, C. J. (2016). Associations between public library use and reading aloud among families with young children. Journal of Pediatrics, 173 , https://doi.org/10.1016/j.jpeds.2016.03.016

[4] Easton, P. (2014). Sustaining Literacy in Africa Developing a Literate Environment. (S. K. and C. A. Margarete Sachs-Israel, Clinton Robinson \& Cover, Eds.). Paris: the United Nations Educational, Scientific and Cultural Organization.

[5] Fountas, I., \& Pinnell, G. S. (2001). Guiding Readers and Writers/Grades 3-6. Portsmouth: NH,Heinemann.

[6] Foy, P. (2017). USER GUIDE FOR THE INTERNATIONAL DATABASE TIMSS 2015 Works User Guide for the International Database.

[7] Foy, P., Aldrich, C. E. A., Fishbein, B. G., Köhler, H., Kowolik, K., Liu, J., ... Yin, L. (2018). PIRLS 2016 User Guide For The International Database.

[8] Frey, B. B., Lee, S. W., Tollefson, N., Pass, L., \& Massengill, D. (2005). Balanced Literacy in an Urban School District. Journal of Educational Research, 98(5), 272-280. https://doi.org/10.3200/JOER.98.5.272-280

[9] Gao, Q., Wang, H., Mo, D., Shi, Y., Kenny, K., \& Rozelle, S. (2018). Can reading programs improve reading skills and academic performance in rural China? China Economic Review, 52(August 2017), 111-125. https://doi.org/10.1016/j.chieco.2018.07.001

[10] Håklev, S. (2010). Community Libraries in Indonesia : A Survey of Government- Supported and Independent Reading Gardens Higher Education and Comparative , International and Development Education Ontario Institute for Studies in Education University of Toronto. Library Philosophy and Practice, 2010, 1-17.

[11] Ibrahim, G. A. (2017). PISA dan Daya Baca Bangsa. Kompas.Com, p. 7.

[12] Law, Y. kum. (2011). The role of teachers' cognitive support in motivating young Hong Kong Chinese children to read and enhancing reading comprehension. Teaching and Teacher Education, 27(1), 73-84. https://doi.org/10.1016/j.tate.2010.07.004

[13] Rojas-Drummond, S., Maine, F., Alarcón, M., Trigo, A. L., Barrera, M. J., Mazón, N., ... Hofmann, R. (2017). Dialogic literacy: Talking, reading and writing among primary school children. Learning, Culture and Social Interaction, $12, \quad 45-62$. https://doi.org/10.1016/j.lcsi.2016.09.005

[14] Shaw, D., \& Hurst, K. (2012). A Balanced Literacy Initiative for One Suburban School District in the United States. Education Research International, 2012, 1-9. https://doi.org/10.1155/2012/609271

[15] Shrestha, S., \& Krolak, L. (2015). The potential of community libraries in supporting literate environments and sustaining literacy skills. International Review of $\begin{array}{lll}\text { Education, } & 61(3), & 399-418 .\end{array}$ https://doi.org/10.1007/s11159-014-9462-9

[16] Stranger-Johannessen, E. (2014). Promoting a reading culture through a rural community library in Uganda. IFLA Journal, $\quad 40(2), \quad 92-101$. https://doi.org/10.1177/0340035214529732

[17] Walker, A. B. (2015). Giving Literacy, Learning Literacy: Service-Learning and School Book Drives. Reading Teacher, 69(3), 299-306. https://doi.org/10.1002/trtr.1394

[18] Wijayanto, N. (2017). Surabaya Adalah Kota Literasi yang Sempurna dan Terbaik di Jawa Timur Bahkan Indonesia. Tribunjatim. Retrieved from http://jatim.tribunnews.com/2017/06/06/surabaya-adalahkota-literasi-yang-sempurna-dan-terbaik-di-jawa-timurbahkan-indonesia

[19] Wilkinson, D., \& Birmingham, P. (2003). Using Research Instruments: A Guide for Reasearchers (First Edit). London and New York: Taylor \&Francis e-Library.

[20] Yektiningtyas-Modouw, W., \& Karna, S. R. W. (2013). Using Folktales to Strengthen Literacy in Papua. Australian and International Journal of Rural Education, 23(3), 94-107 